\title{
THE MODERN STYLE IN INTERIOR AND EXTERIOR DESIGN
}

\author{
Vaska Sandeva, Katerina Despot \\ Goce Delcev University of Stip, Macedonia \\ Krste Misirkov b.b. P.O. Box 201 Stip 2000, Macedonia, \\ e-mail:vaska.sandeva@ugd.edu.mk, katerina.despot@ugd.edu.mk
}

\begin{abstract}
The style is a way of expression, which is characterized by all the features that distinguish it from the rest. In the art indicates overall characteristics of an artist or art school, direction or time. Modern design is difficult to define. The term "modern" refers to the impact of modern art to the design of interiors and exteriors. Modern design is defined more by its own trends, which is largely unchanged for several decades.

One of the most important elements in modern design of interiors and exteriors is the form. Modern design uses geometric forms including rigid squares and rectangles, with a smooth, even and curved ends. Perfect circles and oval shapes are also common in modern design. Modern design is also plain and simple.
\end{abstract}

Keywords: designer, landscape, art, interior, exterior.

\section{INTRODUCTION}

The style can be characterized by art in a certain period of time (Gothic, modern, baroque style or direction), a specific environment (rustic style), particular artist, etc.

The modern style is mainly characterized by simple forms without decorations, while creating beautiful shapes of the structure's elements.

The concept of modern architectural style means more movements and styles, some of which are related, while others are clearly distinguished.

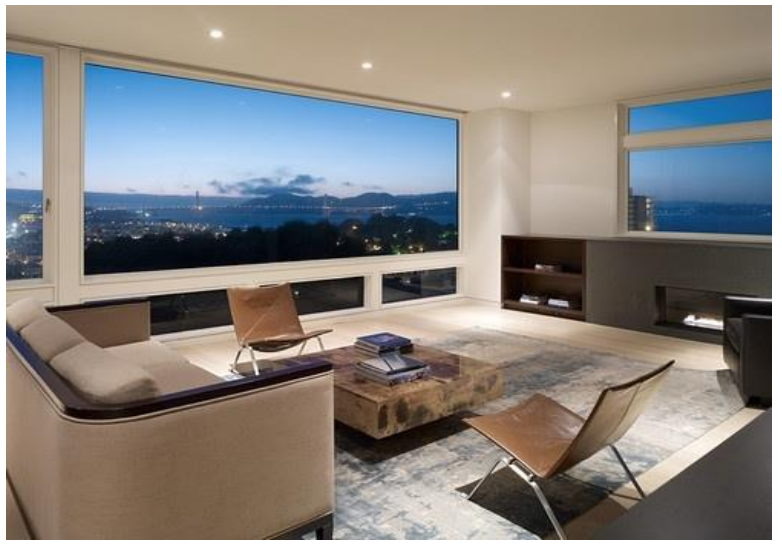

Figure 1. Interior in modern style

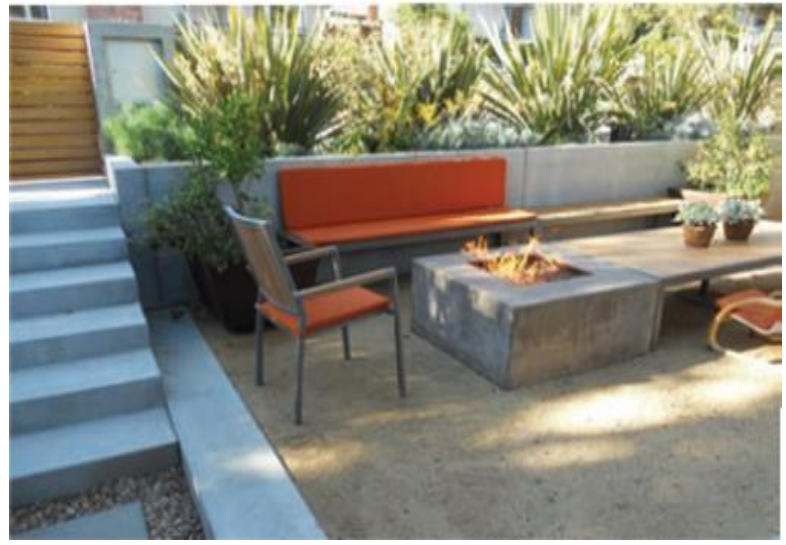

Figure 2. Exterior in a modern style

Modern art as a movement followed the trends of modern design. In painting, modernism began with the impressionists and others that use abstraction in their work. Interior and exterior's modern design is derived from decorative art, particularly art deco, in the late 19th and early 20th century. It reached its peak in the 1950s and 60s. 


\section{ARTTIE Y}

Ipplied Reseirlches in Technics, Technologies ind Bductition

Journal of the Faculty of Technics and Technologies, Trakia University https://sites.google.com/a/trakia-uni.bg/artte/

Modern style as a term often used to describe modernist's movements in the late 20th century, with the rapid technological progress and modernization of society, using new materials and incredibly innovative new designs, making buildings and interior received brand new functions and forms.

The rise of this style is characterized by numerous movements and openings of many schools of design.

While modern design has its roots in the 1930s, modern interiors and exteriors become widespread after the Second World War.

The creation of modern style in the design of interiors and exteriors is credited to a group of European designers which began in the Bauhaus school of design in Germany in 1919.

Bauhaus philosophy is that form and function should be combined in all designs. The modern design style is pure, linear and focuses first and foremost on function and avoids excessive accessories and decorative elements seen in many other styles. Some people feel modern design too simple, rough or cold, but when it is well planned can promote a sense of calm and simplicity.

From its inception to the present, the style has new materials and technology.

The modern design evolved over time and covers a wide range of styles from the midcentury modern to contemporary styles of houses.

Minimum textures and bold geometric shapes, neutral colors accented with color filled with polished ends and asymmetrical balance are key features of the modern style of interiors and exteriors.

\section{DECORATION}

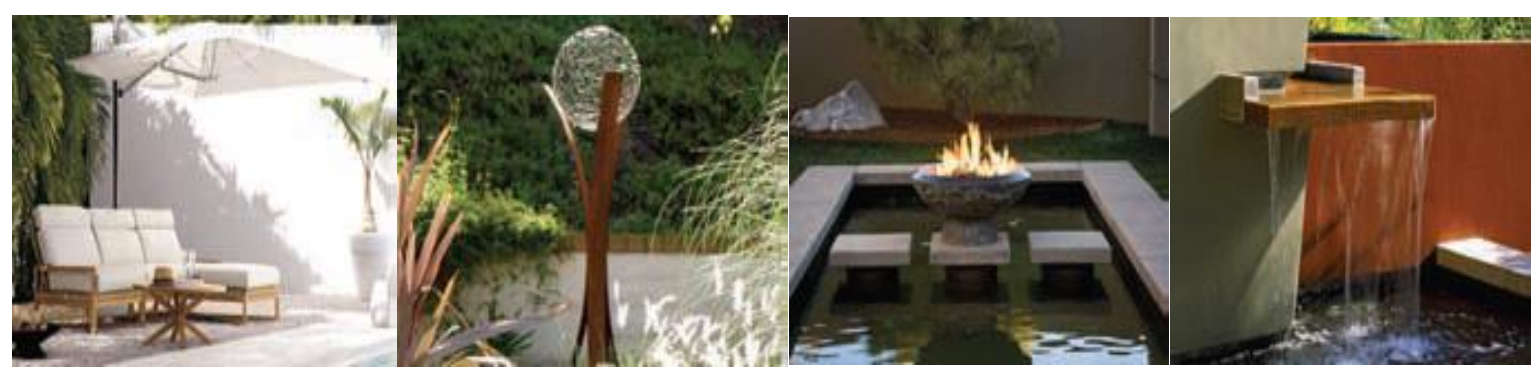

Modern furniture

Modern sculpture

Fireplace

Fountain

The colors should be futuristic, such as silver, bronze and similar "modern" colors.

\section{COLORS}

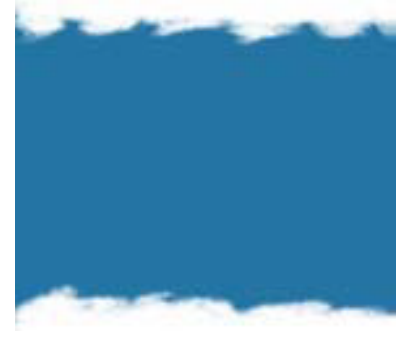

Blue

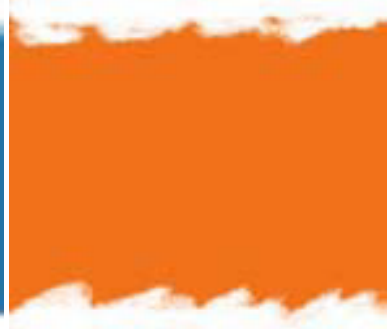

Orange

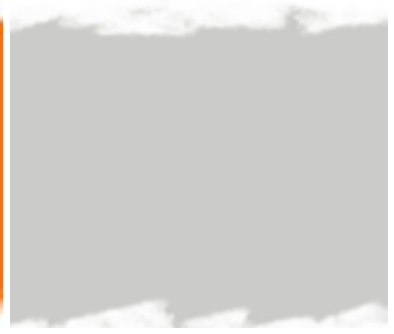

Graщ

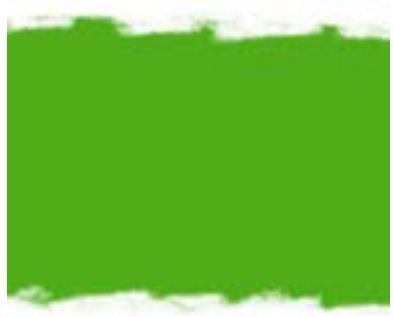

Neon Green

IRTIIE Vol. 4, No. 1, 2016 ISSN 1314-8788 (print), ISSN 1314-8796 (online), doi: 10.15547/artte.2016.01.008 


\section{ARTTIE $Y$}

Ipplied Reseirlores in Teednics, Technologies ind Bductition

Journal of the Faculty of Technics and Technologies, Trakia University https://sites.google.com/a/trakia-uni.bg/artte/

The modern design of the interior uses many different materials. Wood and plastic are common, some designers use natural wood as organic versus artificial forms and materials. Glossy metal such as stainless steel are among materials in modern interior spaces. Designers of modern design interior and exterior also use mixtures of glass and plastic.

\section{MATERIALS}

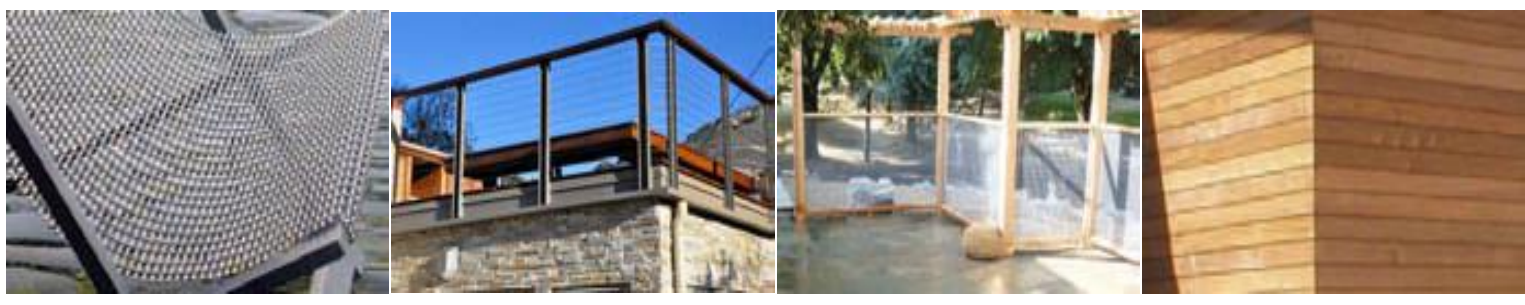

Wire Cable

Car Panel

Wooden

Sheath

\section{PALLET PLANT}

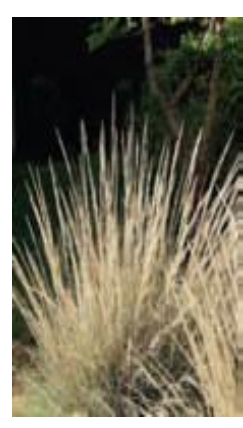

Grass

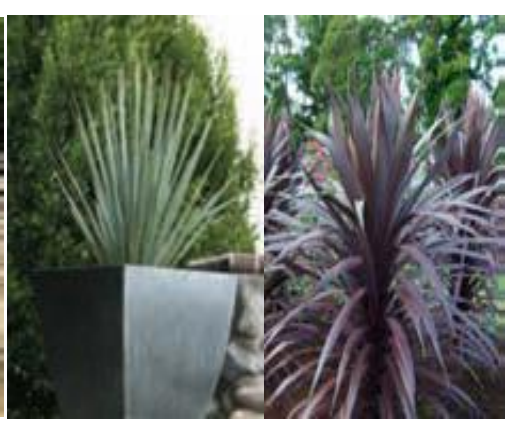

Juka

\begin{abstract}
Palma
\end{abstract}

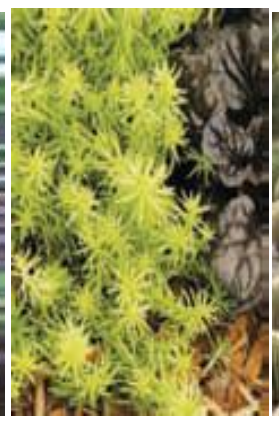

Succulents

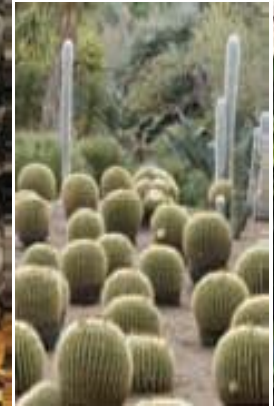

Cactus

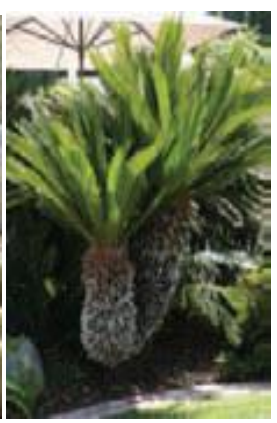

Palma

The space; commitment to all that is linear; windows as part of the design; open creative plans; focus on materials; strict forms and calm colors. Elimination of the familiar, classic "kalpaks" in the family house and yard simplicity; inspired by space, location and function; Only the necessary work involved in the design; decorations are the elements by themselves: walls, windows, ceilings, metal structures; there is no overcrowding and kitsch; The materials used for construction are shown in their natural form, not hidden; Brave horizontal and vertical lines; The windows and doors are characteristic of this style from floor to ceiling; Almost always the topography is incorporated in the design of the house and so on.

\section{SIMPLICITY IN SHAPE AND DESIGN}

Too many decorative elements that give a sense of kitsch are eliminated or greatly simplified, giving the image of a clean, aesthetically landscaped space. Modern taste enjoys the simplicity and clarity.

Clutter and unnecessary elements are abandoned in modern architecture. Project objectives are clear from the start and only functionality is necessary in the design.

The space that is made in a modern style was "stripped" so it will show the architectural design of space - the focus will be exclusively on the space, not the decorations or details that are not relevant to the overall design.

IRTTIE Vol. 4, No. 1, 2016 ISSN 1314-8788 (print), ISSN 1314-8796 (online), doi: 10.15547/artte.2016.01.008 


\section{ART'TE \\ ( \\ Applied Researrohes in Technics, Technologies ind Rducation \\ Journal of the Faculty of Technics and Technologies, Trakia University https://sites.google.com/a/trakia-uni.bg/artte/}

\section{INSPIRED BY FUNCTIONALITY}

Modern architecture aims to create designs that will be above the standard ideas that will primarily be of great benefit.

Louis Sullivan publicly declared that "form follows function". This idea expresses the tendency of the modernists to dictate the ideas of design.

The designers of the modern age have inspiration from the project - if the project aims to show something, for example a house, or to be taken from another person, the architects have to design according to the unique situation and to be inspired by the purpose and functionality of the facility.

\section{NOTHING TO BE HIDDEN}

Instead of concealing the nature of space, modern style viewer wants to have visibility inside the work and the real nature of the project.

Materials are displayed in their natural form.

Structural elements are disclosed to show the structure and support.

Exposed beams, open floor plans, and structural elements are exposed to the viewer.

The idea of a sense of "truth" is present in the space where all materials and architectural elements are bare and honestly revealed.

\section{TRENDS TOWERDS LINES}

In many modern designs, you can find strong linear elements and bold horizontal and vertical features.

Beams, shapes, windows, staircases, fireplaces, roof lines and other structural elements assist the designer in creating a linear inspiring space. This focus is much more famous in modern design, and is less important in other, more traditional styles of building.

The lines of modern architecture tend to be straight and angled instead of curved, organic lines can still play a part to his time in modern design in the home.

\section{USE OF MODERN MATERIALS}

Modern homes often experiment with the latest building materials and techniques.

Many areas built according to modern style use wood as a material.

Steel poles are used in exposed applications, concrete block used as finished material, concrete floors.

Modern exteriors are in most cases stone, plaster, wood, or brick.

A modern design highlights strong and smooth materials, including steel, concrete, chrome and stone.

Exposed beams and opposing wall materials commonly seen inside.

Neutral colors are preferred in modern houses to highlight the materials and design.

\section{USE OF ADVANTAGE OF SUN AND IMPROVEMENT OF HUMAN COMFORT}

Best modern spaces are efficient with use of the home. They are oriented to take advantage of natural forces.

Homes made in a modern style providing solar heating in winter and in summer provide shade from the sun, so prevent entry of excessive heat in the house, and thus preserving the comfort of the air in summer. 


\section{ARTTIE $Y$}

Ipplied Reseirlches in Technics, Technologies ind Eductation

Journal of the Faculty of Technics and Technologies, Trakia University https://sites.google.com/a/trakia-uni.bg/artte/

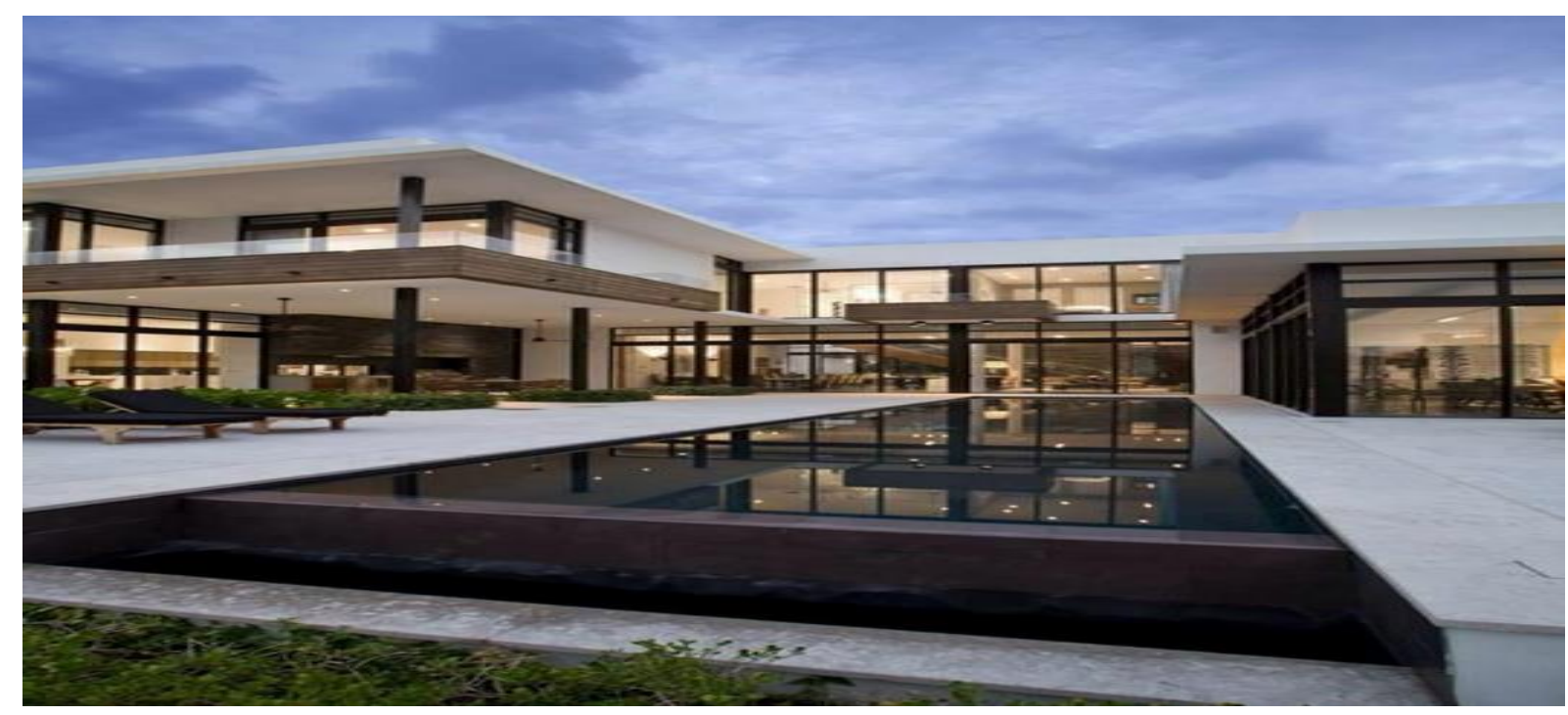

Figure 3. Pool in the modern style, characteristic is infinite pool; There are no curves, circles, ellipses; The rectangular shape dominated; Pure linear forms
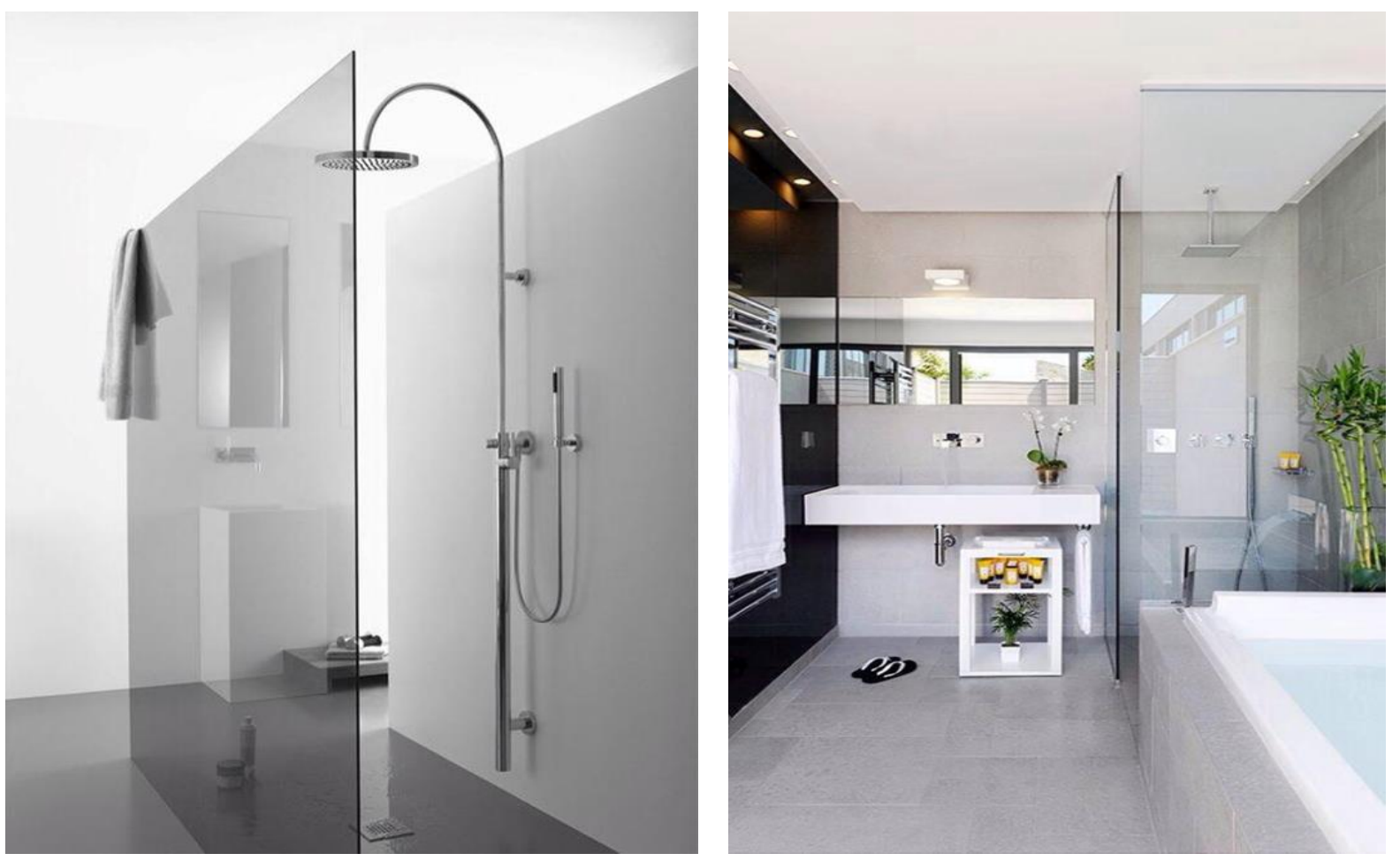

Figure 4. Bathroom - Minimum decorations; Metallic elements, natural colors - gray, white, brown; Large windows, plenty of light; Simple mirrors and rectangular shapes of the sink, doors and hanging elements 


\section{ARTTIE $Y$}

Ipplied Reseirlches in Technics, Technologies ind Eductation

Journal of the Faculty of Technics and Technologies, Trakia University https://sites.google.com/a/trakia-uni.bg/artte/

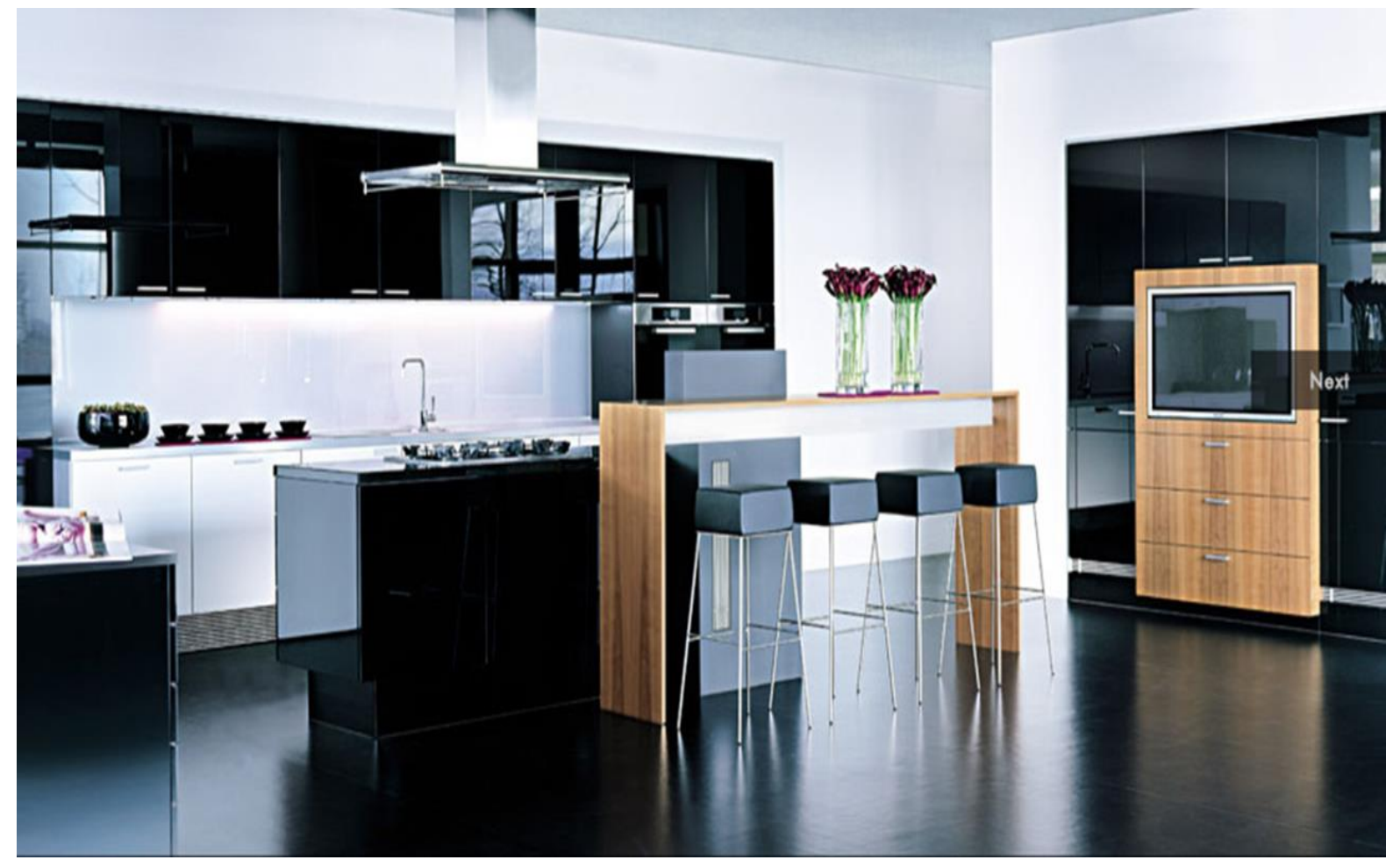

Figure 5.

Kitchen - Open, large; Horizontal and vertical lines; Sharp corners, clean shapes; Major elements and calm colors; Tall windows, simple bars

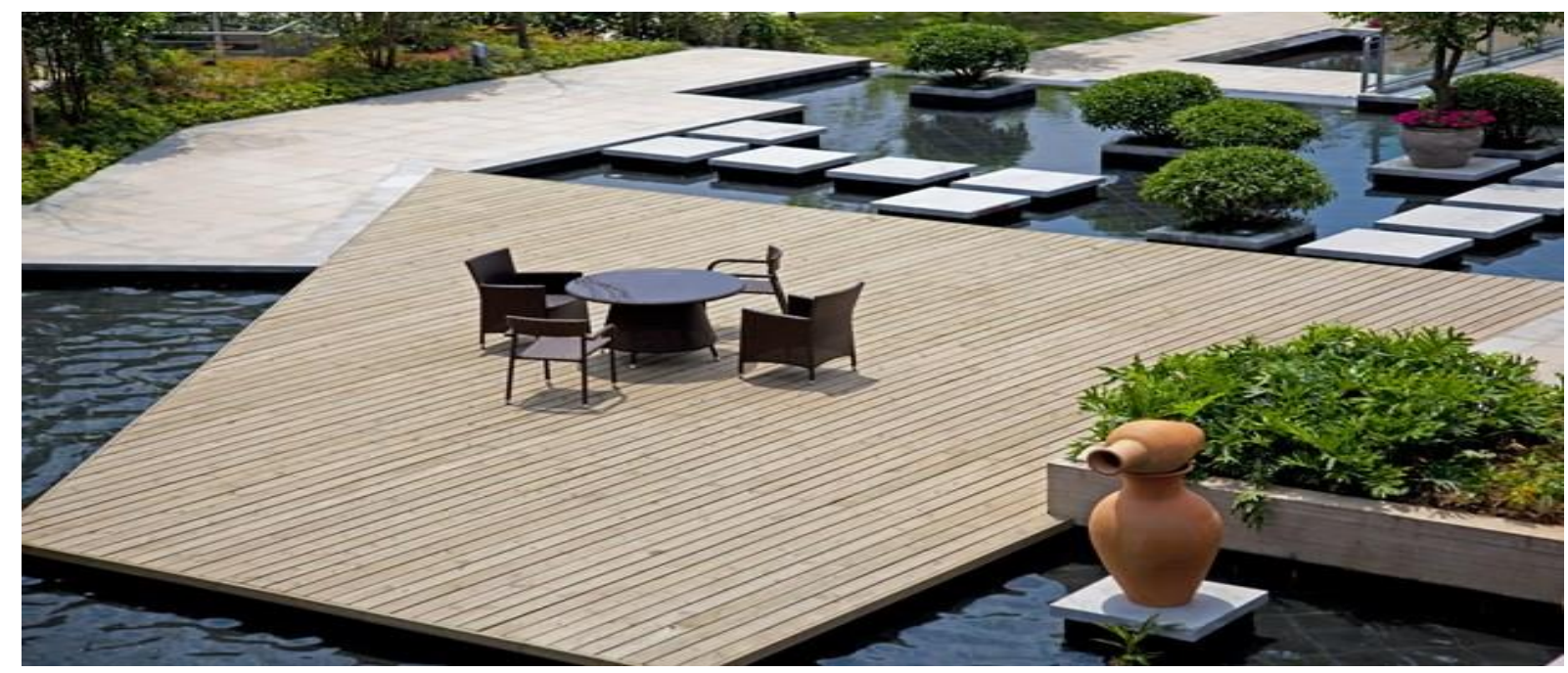

Figure 6.

Features Kitchen - Open, large; Horizontal and vertical lines; Sharp corners, clean shapes; Major elements and calm colors; Tall windows, simple bars 

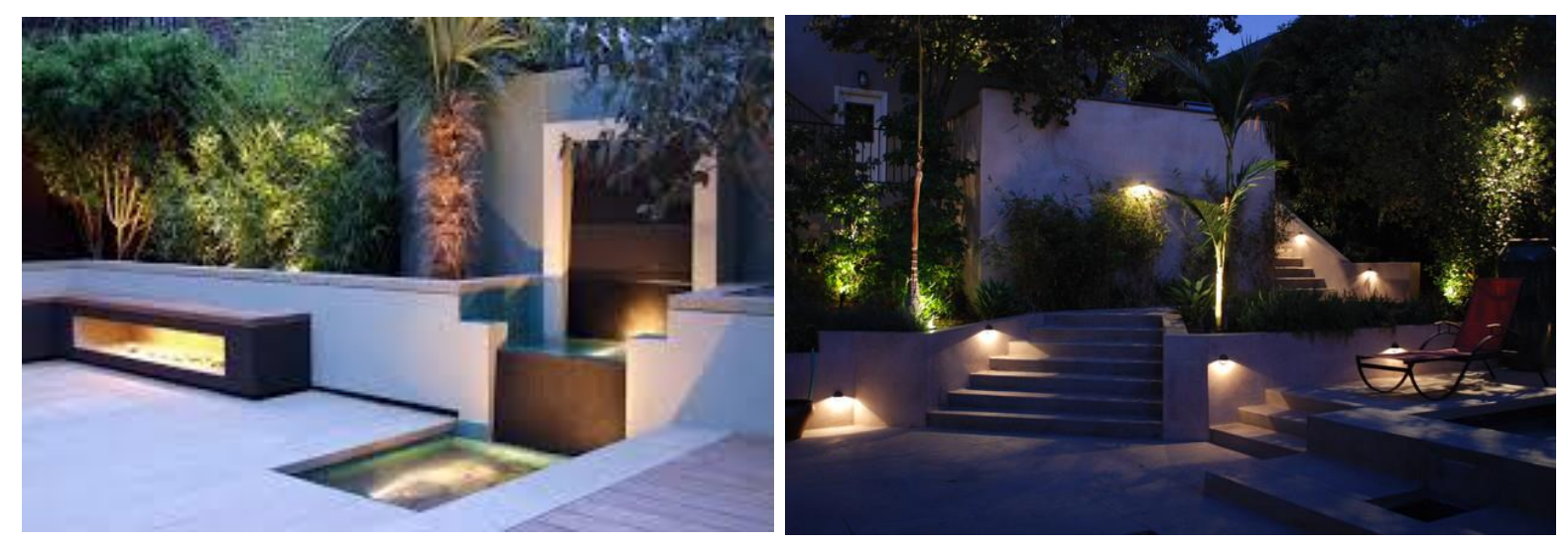

\section{CONCLUSION}

The main features of modern style in interior design and exterior are clean linear design, function over form, avoiding too many embellishments, minimal use of textures, asymmetrical balance, simple shapes and design.

Modern style has a few things in which they contrast from other styles. The focus initially is on simplicity and asymmetry.

Modern style is ideal for small spaces, because it maximizes the functional space and creates the impression that the space is larger than it really is.

\section{LITERATURE}

[1] Christopher Tunnard. Gardens in the modern landscape. 2014.

[2] Emily Chalmers, Ali Hanan. Modern Vintage Style. 2011.

[3] Emily Henson. Bohemian Modern. 2015.

[4] Fomina, L. Osnovi na parkovoto iskustvo. Sofia, 1988.

[5] Susan Fazckas. In the modern style. USA, 2003. 